\title{
ПРИЛОГИ О ЗДРАВСТВЕНЕЙ КУЛТУРИ И ЗАЩИТИ У ВИДАНЬОХ РУСКОГО НАРОДНОГО ПРОСВИТНОГО ДРУЖТВА $(1921-1941)^{*}$
}

Абстракт: У своєй всестраней и богатей дїялносци Руске народне просвитне дружтво у периодзе медзи двома шветовима войнами вельку увагу пошвецовало подзвигованю общого уровня културно-просвитного и ширше дружтвеного та и привредного живота Руснацох у Кральовини СГС/Югославиї. Як окремна обласц тей дїялносци вшелїяк и намаганя у подзвигованю уровня общей здравственей култури и здравственей защити, цо будзе главна тема тей нашей виглєдовацкей роботи.

Ключни слова: Руске народне просвитне дружтво, Руснаци у Югославиї, Руски календари, Руски новини, здравствена култура, здравствена защита, обераци хороти.

У историографиї о Руснацох у Южней Угорскей практично нєт прилоги котри би ширше и систематично спатрали здравствени обставини або питаня здравственей защити медзи нїма. Одредзени податки о здравствених обставинох у XIX вику дава Гавриїл Костельник у своєй Хронїки Руского Керестура, дзе углавним на основи податкох з церковних матрикулох указує природни прирост у одредзених периодох и окреме спомина роки кед ше зявйовали даєдни обераци хороти котри одношели преважно дзецински животи. То роки кед, звичайно пре вельку смертельносц дзецох, морталитет бул векши од наталитету (Костельник 1998: 39). Дакус вецей податки у историографиї єст о вельких епидемийох колери у Керестуре 1836, 1848/9. и 1873. року, котри спомнути и у хронїкох Керестура (Рамач 1988: 530), а о нїх даваю надосц податки и Гавриїл Костельник (Костельник 1998: 39), Мирон Жирош (Жирош 1984) и Янко Рамач (Рамач 2007: 204-2008). О епидемийох колери у Коцуре 1831. и хороти под час вельких водох 1870-1872. року спомина у своєй историї коцурскей парохиї Павло Вукич (Вукич 1996: 91-92, 96-97), а народни хронїчар Йоан Москаль погришно датує колеру 1831. року з 1829. роком (Москаль 1923: 79). Вецей о колерох у Коцуре дава М. Жирош (Жирош 1986). Найобширнсйше о початку, ширеню, цеку и бор- 
би процив епидемиї колери у Керестуре и Коцуре бешедую звити месних парохох (Рамач 2007: 204-208). Тота епидемия, як ше видзи з тих звитох и описох, однєсла велї жертви и пре нїзки общи уровень здравственей култури и здравственей защити, пре пожнєнє з мирами же би ше цо швидше и ефикаснєйше застановела и пре нєдосток и фаховей служби и лїкох за лїченє тих цо ше уж похорели.

О здравствених обставинох медзи Руснацами у Югославиї барз кратко спомина лїкар и историчар Ристо Єремич (Јеремић 1928: 60), алє хаснує лєм податки зоз статї коцурского лїкара др Осифа Полиха (Полих 1925: 97-99), о котрей ище будзе слово.

У апелу Дюри Биндаса и Михайла Гайнала з новембра 1913. року, котри адресовани рускей интелигенциї з предкладаньом же би ше од початку 1914. року почало видавац єдни тижньово або двотижньово руски новини, а по можлївосци и календар, наводзи ше цо би бул циль тих новинох, и окрем иншого, назначене и "одучованє народу од злих обичайох" (Биндас - Гайнал 1937: 2). Зоз формулациї "одучованє народу од злих обичайох" нє мож точно заключиц цо под тим авторе точно подрозумйовали, алє познєйше, кед уж почали виходзиц Руски новини, ${ }^{1}$ у нїх обявйовани тексти о "нєдобрих народних обичайох", а ту ше медзи иншим наводзи обичай и часта пракса Руснацох же ше причина велїм хоротом глєда у рижних врачанїнох и поробенїнох, та ше у врачанїнох часто глєдало и лїк за тоти хороти, а то ше нєгативно одражовало на лїченє у велїх случайох. То источасно и свидоцтво о нєзадоволююцих здравствених обставинох медзи Руснацами у тим чаше (Биндас 1926: 23-24; Кочиш 1930: 1). Тота тема як слика каждодньового живота Руснацох була присутна и у медзивойновей и повойновей рускей литератури, у приповедкох Михала Ковача, Евгения Кочиша, Дюри Латяка и других.

Гоч Руске народне просвитне дружтво, основане 1919. року (далєй: РНПД), у своїх Правилох (Правила 1921: 8-12) нє наводзи як обласц свойого дїлованя и старосц о здравствених обставинох Руснацох у держави, од початку видаваня Рускойо каленgара ${ }^{2}$ у нїм єст тексти пошвецени здравю народу. У першим медзивойновим Руским каленgаре обявена статя котра у ширшим розуменю бешедує о здравствених обставинох медзи Руснацами у Югославиї. Михайло Черняк у статї о алкоголу и алкоголизму досц нашироко бешедує о алкоголу як о вельким нєприятельови чловекового здравя, а источасно описує и чкодлївосц алкоголу за здравє цалого народу (Черняк 1922:85-91).

У чаше медзи двома шветовима войнами медзи Руснацами у Югославиї були досц розширени рижни обераци хороти, прето у виданьох РНПД), у Руских новинох и у Руских каленgарох вельке значенє мали тексти лїкарох

Руски новини - орган Руского народного просвитного дружтва, тижньово новини котри виходзели од 1924-1930. у Новим Садзе, 1931-1936. у Дякове и од 1937. по 6. април 1941. року у Р. Керестуре.

2 Руски календар - рочна кнїжка котру видавало РНПД од 1921-1941. рок. 
котри були пошвецени опису даєдних хоротох и їх лїченю, або просто намаганю воспитовац людзох у обласци здравственей култури и чуваня/защити здравя. Таки прилог лїкара Янка Жилника $O$ gаскелїх оберащих (йоряgкових) хоройох, у котрим вон перше дава основни надпомнуца о защити здравя, окреме наглашуюци яку ту улогу ма чистота у биваню, превитрйованє просторийох и чуванє здравих членох фамилиї од хорого кед тот ма даяку оберацу хороту. Жилник дава кратки опис 10 оберацих хоротох по тим шоре: дифтеритис (гуга), шарлах (моровки), осипки, чарни поки (вельки поки), магарчи кашель, инфлуенца, пегави тифус, тифус у бруху, грижня (дизентерия) и колера. За тоти хороти назначене як ше ширя и як ше од нїх треба чувац. Од велїх найлєпша защита вакцина (Жилник 1922: 115-116).

Кед у децембру 1924. року почали виходзиц Руски новини, такой у перших числох ше зявели прилоги на тему "Народне здравє". Понеже ше у тим чаше у Кральовини СХС ширела обераца хорота черевов тифус (глушка горячка), др Я. Жилник написал о нєй кратки прилог (Жилник 1924: 3-4). Вон наводзи же то чежка обераца черевова хорота котра ше преноши найвецей з брудну воду, з бруднима руками и брудну овоцу. Ту лїкар спозорює же би ше нє ходзело до тих обисцох дзе дахто ма черевов тифус прето же ше тота хорота лєгко преноши. Найлєпше ше мож чувац од нєй зоз чистоту и чисту студню/чисту воду. Медзитим, барз важне и елиминовац жридло з хторого ше хорота шири, прето лїкар наглашує же вода односно студня у котрей єст бактериї тифусу барз опасна за здравє людзох и статку та ю треба засипац. Далсй наводзи же ше од тей хороти мож защициц зоз вакцину. На концу описує як ше манифестує хорота черевового тифусу же би людзе лєгчейше препознавали єй симптоми и же би, кед зрозумя же ше роби о озбильней оберацей хороти, на час глєдали помоц од лїкара и так помогли и себе и нє дошлєбодзели же би ше вона ширела найбаржей пре нєзнанє же ше роби о чежкей оберацей хороти.

Руснаци у Южней Угорскей у XIX вику од власней интелигенциї мали лєм священїкох и учительох, од котрих велька часц нє мала одвитуюце образованє, а нє мали велї фахи високообразованей интелигенциї як цо то правнїки, адвокати, инжинєре, професоре, апатикаре, лїкаре итд. Перши лїкаре и апатикаре при Руснацох зявюю ше у руских населєньох аж у чаше медзи двома шветовима войнами, прето у Руских новинох були обявйовани рижни вистки котри повидомйовали о лїкарох, о апатикарох и о отвераню нових апатикох. У новембру 1926. року у Руских новинох обявена вистка же Министерство здравя дошлєбодзело же би апатикарка Єлена Солонар отворела у Р. Керестуре апатику. До теди у валалє нє було апатики, прето ше у вистки наводзи же то будзе барз вельо значиц жительом Р. Керестура прето же нє буду мушиц ходзиц по лїки до других валалох (Аноним 1926: 3).

Гавриїл Костельник наводзи же у першей половки XIX вику у Керестуре було роки кед очиглядно даєдни обераци хороти одношели велї дзецински животи, алє нє наводзи о котрих хоротох слово (Костельник 1998: 39). Мирон 
Жирош у своїх демографских виглєдованьох преглядно указує наталитет и смертельносц у населєньох дзе у векшим чишлє жили Руснаци од конца XVIII по половку XX вику, алє з тих податкох нє мож утвердзиц точнєйши проценти смертельносци дзецох (Жирош 1997). Перши писани податки о смертельносци дзецох у Р. Керестуре и Коцуре дава др Осиф Полих з Коцура за 1922. рок (Полих 1925: 97-99). Ту од голих числох можебудз же ище застарююцше його толкованє же Руснаци у Р. Керестуре и Коцуре у газдованю и шпоровносци нє заоставаю за сушеднима нємецкима валалами, алє су по общей здравственей култури и защити на нїзким уровню. Вон твердзи же барз часто присутна очиглядна нєдзбалосц же би ше хорого на час одведло до лїкара. Исто так указує же при Руснацох присутне и вельке нєдовириє людзох до лїкара и медицини, а по його твердзеню людзе маю векше довириє до врачаркох котри нїч нє помагаю, а представяю вельку чкоду народному здравю. Податок же у Коцуре од 96 умартих у 1922. року 47 нємовлятка - дзеци до єдного рока, а у Р. Керестуре од 126 умартих - 44 нємовлятка би можебудз нє випатрал так забригуюцо, кед би др Полих ту нє приложел поровнанє зоз сушеднима нємецкима населєнями, зоз котрого ше видзи же у Вепровцу (Крушчичу) у истим року од 47 умартих лєм 4 дзеци нємовлятка, а у Торжи од 53 умартих 6 дзеци до єдного рока живота. По Полихови така статистика реална слика здравствених обставинох медзи Руснацами у Бачки. Правда, на основи статистичних податкох за єден рок нє мож приношиц заключеня же таки обставини нєпреривно пановали, алє их исто так нє мож звесц лєм на "усамени случай" того року, поготов же ту дати податки за два руски и за два нємецки населєня, котри барз индикативни.

Дохтор Полих далєй толкує же одношенє Руснацох, поготов мацерох, гу своїм новородзеним дзецом од перших годзинох дзецкового живота часто нательо погришне и чкодлїве за дзецко, же праве то водзи до такей високей смертельносци нємовляткох. Як перше, по нїм то повязованє дзецом ручкох и ножкох зоз пантлїками и закруцанє до перинкох на таки способ же ше дзецко нє може шлєбодно рушац. Далєй наводзи же єст вельо нєправилносци у дойченю дзецох, а поготов у їх карменю у перших тижньох и мешацох. По нїм, при Руснацох пракса же би ше и дво-тро тижньовому дзецку давало гурки и колбаси, бо то нїби помага же би дзецко змоцнєло, а то уствари барз чкодзи слабому дзецковому жалудку. Др Полих тиж так трима же велька причина хоротох та и високей смертельносци дзецох факт же зоз малима дзецми вельо часу препровадзую нє їх мацери, алє стари баби. Спомина же при Руснацох обичай же би ше малим дзецом жувало єдзенє котре вони сами нє можу пожувац, и вец ше им пожуване дава до устох. То обично робя баби, котри найчастейше з дзецми, а таки баби звичайно маю погубени зуби, та ше так з таким карменьом на дзеци преноша велї бацили котри им спричинюю рижни хороти. 
Добре же лїкар у статї нє остава лєм на тих констатацийох, алє вше дава и совит цо и як би требало правилно робиц. На концу заключує же будзе задовольни кед голєм єдна од тисяч мацерох прилапи його совити, прето же то будзе важни крочай гу здравю єй дзецох, а вироятно и початок у меняню нєдобрих обичайох и пракси у допатраню нємовляткох.

Висока смертельносц нємовляткох у тим чаше була присутна нє лєм при Руснацох и нє лєм у валалских стредкох у Войводини, алє и у городзе Н. Садзе. Нє уходзаци глїбше до розпатраня общих здравствених обставинох у городзе, наведземе лєм становиско лїкара виглєдовача Петра Микича, котри як основни причини високей смертельносци нємовляткох у Н. Садзе у периодзе медзи двома шветовима войнами наводзи: нєдостаточно фахове водзенє породзеньох односно породзованє дома, часто и без бабици, нєправилне карменє, нєгигиєнски условия живота, велька можлївосц инфекциї поготов у пригородских и руралних стредкох, велька завжатосц з роботу женох у худобнєйши пасмох жительства котри ше лємцо породзели итд. (Микић 1989: 75). Очиглядно, велї од тих наводзених причинох ше одноша и на смертельносц нємовляткох у Р. Керестуре и Коцуре.

Статю о допатраню дзецох у першим року живота опубликовал и керестурски лїкар др Андрий Наливайко (Наливайко 1935: 146-152). И вон наводзи же велї дзеци при Руснацох умераю уж у першим року живота лєм прето же мацери нє знаю як их треба виховйовац. Наливайко приклада и табелу на основи провадзеня обставинох през дзешец роки, по котрей, кед ше у Р. Керестуре стреднє рочно народзовали 202 дзеци, умарло 41 дзецко од 1-2 рокох, 12 од 1-5 рокох, 4 од 5-10 роки и 3 од 11-15 роки. (Наливайко 1935: 146). Нажаль, ту ше нє наводзи од котрих хоротох дзеци умерали. Найвецей поуки и совити дохтор дава мацером о тим як треба кармиц дзеци у першим року живота, а вец дава ище 15 рижни совити, од отримованя чистоти, карменя дзецка, чуваня дзецка же би ше на ньго нє пренєсли обераци хороти и так далєй. Сам препатрунок тих совитох указує же дохтор инсистує же би ше пременєла прилапена пракса котра негативно дійствує на розвой и здравє дзецка.

Зоз податкох котри дава П. Микич о умераню дзецох у Н. Садзе 1925. року нє мож заключиц яки бул того року процент смертельносци дзецох, алє ту дати податки о тим котри хороти и у котрих рокох живота найвецей одношели дзецински животи: так 25\% дзецох од 1-3 роки живота умарли од охореня органох системи диханя, од хороти органох за варенє $16,6 \%$, од шарлаху $16,6 \%$, од менингитису $12,5 \%$, од конвулзиї $8,35 \%$, од пертусису $8,35 \%$ итд. Кед слово о старших дзецох, тих од 4-6 и од 7-14 роки, ту найчастейши причини шмерци хороти дигестивного тракту, епилепсия, менингитис, пнеумония, шарлах, тетанус, черевов тифус и други хороти (Микић 1989: 78-79). Вшелїяк же значна и констатация П. Микича же у периодзе медзи двома шветовима войнами у Н. Садзе и ширше у Войводини диягнозу шмерци треба брац з одредзену дозу резерви, прето же причи- 
ни шмерци нє вше були достаточно фахово констатовани, бо то нє вше робели лїкаре (Микић 1989: 85).

У Новим Садзе у периодзе медзи двома шветовима войнами процент смертельносци дзецох нєпреривно опадовал, та кед 1920. року од вкупного числа умартих смертельносц дзецох по 14 роки живота виношела $32,46 \%$ проценти, после того тот процент опадовал и 1940. року процент смертельносци дзецох виноши лєм 17,48\% од вкупного числа умартих. То очиглядно резултат злєпшованя общих здравствених условийох и систематичнєйших акцийох на здравственим просвищованю ширших пасмох народу, алє тиж так и вше интензивнєйшого хаснованя вакцинох, превентивней медицини (Микић 1989: 74-75). Чкода же нє маме податки за Р. Керестур, Коцур або даєдно друге руске населєнє о рушаню смертельносци дзецох у одношеню на смертельносц одроснутих у чаше медзи двома войнами, же би ше видзело чи ше и при Руснацох так случовало. То би практично бул и одвит на питанє кельо намаганя медицинских роботнїкох котри зоз своїма прилогами у виданьох РНПД доприношели же би ше зоз подзвигованьом общей здравственей култури реално зменшовал процент смертельносци у одношеню на наталитет. За Р. Керестур и Коцур у периодзе медзи двома шветовима войнами М. Жирош дава податки о числу народзених и умартих за кажди рок (Жирош 1997: 409-411). По нїх, у Р. Керестуре од 1921-1930. рок умарло 62,74\%, а од 1931-1940. рок - 64,75\% од вкупного числа народзених, а у Коцуре од 1921-1930. рок умарло 55,27\%, а од 1931-1940. рок - 71,08\% од вкупного числа народзених. Значи, по тих податкох смертельносц у тих двох руских валалох у наведзеним периодзе ше звекшовала, з тим же у Р. Керестуре у штвртей децениї у поровнаню з трецу наталитет опаднул коло $21 \%$, а морталитет опаднул коло $19 \%$, а у Коцуре у штвартей децениї наталитет опаднул у поровнаню з трецу коло $35 \%$, а морталитет зменшани лєм за коло $22 \%$. Нажаль, нє познати нам причини того зменшованя числа и народзених и умартих, поготов значного опадованя наталитету у Коцуре у поровнаню з морталитетом, та на основи самих статистичних податкох нє можеме виношиц даяки валидни заключеня.

Др Андрий Наливайко написал даскельо прилоги о оберацих хоротох. У єдним од нїх бешедує вообще о оберацих хоротох и толкує яки то хороти, хто их спричинює и наглашує же даєдни обераци хороти можу мац лєм людзе, а даєдни и людзе и даєдни животинї. Далєй толкує як ше микроби уноша до людского организма, як ше организм бори процив нїх та ше дакеди вибори, а дакеди нє ма досц моци и особа ше похори. Основне питанє на котре дохтор сце дац одвит и совит як ше бориц процив бактерийох же би чловек нє охорел на оберацу хороту. Як перши способ то изолация здравих од жридла оберацей хороти, у першим шоре од того котри ше уж похорел. Далєй шлїдзи дезинфекция односно знїщенє жридла оберацей хороти зоз физичнима або хемийнима средствами. Хорого чловека треба лїчиц и, по 
словох лїкара, нє треба преставац з лїченьом анї теди кед ясне же хороту нє мож вилїчиц.

По словох А. Наливайка найвекши приятель оберацих хоротох нєчистота: нєчистота цела, очох, рукох, лїца, нєчистота у хижи, нєчисти ручнїки, нєчисти посцелї, лавори за умиванє, патос. 3 добрим умиваньом ше знїщує велї бактериї. Напроцив, найвекши приятель и защита од оберацих хоротох чистота. Прето найменєй обераци хороти єст там дзе ше меркує на чистоту цела, чистоту у хижох, ручнїкох, посцельох, дзе ше превитрює хижи итд. Ту дохтор наводзи же при Руснацох часто пракса же и там дзе людзе маю вецей просториї и посцелї часто ше збиваю и шпя у єдней просториї и по вецей особи на єдней посцелї, а то барз нєздраве. Вон твердзи же людзе найчастейше сами виновати кед ше похоря на оберацу хороту, а главна причина тому нєчистота, слаба гигиєна. Далєй наводзи же здрави чловек, тот цо умерено жиє, котри нє ослабює свойо животни сили, ма вецей моци вибориц ше процив оберацих хоротох. На концу заключує же ше єден чловек з власнима моцами нє може вибориц процив оберацих хоротох, бо за тото потребна велька усиловносц и дзбалосц цалей заєднїци (Наливайко 1928: 114-116).

Можебудз же тоти описи и толкованя о оберацих хоротох, їх ширеню и борби процив нїх нєшка випатраю анахроно, алє треба мац на розуме же вони писани у другим чаше, кед обща здравствена култура и способ живота звичайних людзох були на вельо нїзшим уровню, и кед требало укладац вельо усиловносци же би ше здобуло довириє людзох до лїкарох, до лїкох и до лїченя.

У статї Чуванє здравя (Наливайко 1936: 124-127) др Наливайко такой на початку наглашує же под тим подрозумює найбаржей чуванє од оберацих хоротох. По його думаню у новших часох єст вше менєй опасносци од оберацих хоротох и вельких епидемийох, котри дакеди грожели жительтву, прето же ше вше баржей водзи организована борба процив ширеня таких хоротох, починаюци од державного уровня, на котрим ше вельо роби же би ше ширенє таких хоротох застановело такой кед ше зявя. Други уровень котри вельо помага же би ше обераци хороти нє зявйовали и нє ширели то наука и просвищеносц, бо вони помагаю и уча людзох бориц ше процив таких хоротох. При Руснацох важну улогу у борби процив ширеня оберацих хоротох ма и РНПД односно Руски календари и Руски новини котри вельо доприноша же би ше дзвигало уровень общей здравственей култури и гигиєни. Нажаль, констатує др Наливайко, и худобство барз часто причина ширеня оберацих хоротох, бо там дзе худобство часто и нєздрави хижи, менша гигиєна итд.

За здравє, як поєдинцох так и заєднїци, барз важне же би мали здраву воду. Дохтор Наливайко укзує зоз статистичнима податками як ше у Р. Керестуре рушала односно зменшовала смертельносц у єдним року и заключує же вона опадовала од 1927. по 1934. рок вшелїяк дзекуюци и факту же у 
валалє була викопана артейска студня. По його прешвеченю, вода була тот одлучуюци фактор же зменшана смертельносц, бо праве у тим чаше значно зменшани черевов тифус, котри скорей бул части пре нєздраву воду и одношел велї животи.

По твердзеню А. Наливайка у Р. Керестуре ище вше досц присутни два хороти процив котрих ше треба "зос шицкима силами бориц". То туберкулоза/єфтика и трахома, "и єдна и друга хорота страшна и чежка". Факт же тоти два хороти нє присутни лєм у Р. Керестуре, алє у цалей держави, а трахома найбаржей у Войводини, нє шме буц даяке оправданє. Дохтор трима же за присутносц туберкулози у велькей мири вина у нєзнаню. Дзе народ просвищени, там ше баржей дзба о гигиєни и там тей хороти єст вельо менєй.

О оберацих хоротох др Андрий Наливайко обявел и окремну статю (Наливайко 1928: 114-116). На початку перше у основних рисох описал як були пренайдзени микроорганизми котри преноша обераци хороти, як ше вони преноша и як ше людзе од нїх можу чувац и защициц. По дохторови то изолованє хорого од здравих, дезинфекция, лїченє. По його твердзеню найвекши приятель оберацих хоротох нєчистота, а зоз чистоту ше забива преношительох оберацих хоротох.

Обширнсйшу статю о оберацих хоротох дзецох обявел и др Осиф Полих (Полих 1940: 154-160). После кратшого уводу описує як зоз вакцинами мож зачувац дзеци од оберацих хоротох, а окреме описує седем обераци хороти, їх зявенє, манифестованє, лїченє, пошлїдки и чуванє од нїх. То хороти то: поки, гуга (дифтерия), моровки, осипки, магарчи кашель, склопци (тетанус) и збешнєтосц.

Оскар Андрей Лабош пририхтал интересантну статю о першей помоци у рижних нєщешлївих ситуацийох и при нєщесцох рижних трованьох (Лабош 1931: 140-147). Автор дава найосновнейши толкованя и совити цо треба робиц 3 гирями и опухнуцами од вдереня, як третировац одредзени рани, опеклїни, змарзлїни, як помагац задавеному у води, як задавеному з гасом, як помагац у рижних других трованьох итд. На концу дава таблїку у котрей преглядно приказани одредзени трованя и кратки описи як дійствую отрови и як лїчиц отрованого з нїма.

Очни лїкар Олга Палич-Санто у окремним прилогу дава кратки опис причинох шлєпосци (Палич-Санто 1932: 117-119) и наводзи даєдни очни хороти и у найкратших рисох указує як ше мож од нїх чувац. Авторка бешедує о уродзеней и здобутей шлєпосци и наглашує же ше о уродзеней шлєпосци менєй зна и же ше може одклонїц лєм у огранїченей мири. Вона главну увагу обраца на чуванє од очних хоротох и наглашує же и найменши очкодованя и рани на очох треба лїчиц же би нє спричинєли векши очкодованя котри можу привесц до шлєпосци. Як часту очну оберацу хороту наводзи трахому, котра ше досц швидко преноши. Прето зоз ню треба буц барз осторожни. Найчастейша є медзи худобнима, дзе ше менєй дзба о гигиєни. Причини очних хоротох вельораз можу буц други кревово хороти як цо то си- 
филис, туберкулоза и други. И при реуматичних хоротох, ангини, грипи и черевових хоротох окреме треба мерковац же би хорота нє прешла и на очи.

Апатикарка Єлена Солонар пририхтала окремни прилог о тим як треба кармиц мали дзеци (Солонар 1940: 160-164). Солонарова на початку спомина же єй велї хори и слаби жени у апатики поставяли питаня як маю кармиц свойо дзеци. О тим питаню вона ше обрацела гу єдному лїкарови специялистови котри велї роки робел у дзецинскей клиники у Берлину и достала од нього велї фахови поради. Наяр 1939. року у Просвитним доме у Р. Керестуре отримала о тим преподванє, а сам прилог котри дава уствари тото викладанє у писаней форми. Солонарова дава поради и совитує як кармиц дзеци од дойченя по карменє на фляшку и додаванє у першим року живота другого єдзеня.

Апатикарка наглашує же за мале дзецко нєт лєпшого єдзеня од мацериного млєка, прето же мацерине млєко нє лєм найидеалнєйше єдзєнє за дзеци, алє же их воно чува од велїх хоротох. Прето дзецко мож почац кармиц на фляшку лєм кед то дохтор одредзи, односно кед мац барз хора. Солонарова далєй толкує як и кельо дзецко у першим року живота ма цицкац и кеди, як и яке єдзенє му мож почац давац и помали го одучовац од цицканя. Окремни упутства дава як кармиц слаби дзеци котрим и мацери слаби и нє маю досц млєка. Ту ше треба притримовац дохторових препорученьох и совитох. На концу апатикарка подробно описує як ше за мали дзеци пририхтує "рискашова слизаста юшка", "кексова мука" и "маслова юшка". Окреме описує як ше пририхтує малинов сок, котри, по єй словох, барз здрави нє лєм за мали дзеци и прето би кажде обисце требало мац малини.

У остатнїм медзивойновим Руским каленgаре апатикарка Є. Солонарова ма два прилоги. У першим накратко описує приручну апатику (Солонар 1941a: 133-137), котра би ше, по єй совиту, требала находзиц у каждим обисцу, поготов на салашох, одкаль дакус далєй и чежше сцигнуц до лїкара. Вона трима же би по валалох частейше требало организовац "самарянски течаї" - курси у котрих би ше жени и млади дзивки оспособели за даванє першей помоци, а же би ше лїкара волало лєм кед за то постої потреба. Далєй авторка наводзи цо би ше мушело находзиц у приручней апатики у каждим обисцу и толкує кеди и як ше хаснує кажди од наведзених лїкох/ препаратох. Наводзенє тих лїкох и препаратох тераз нє тельо интересантне, бо ше за седем и вецей децениї барз вельо пременєло и у способе лїченя и у назвох лїкох. Ту важнсйша основна намира авторки: дац совити о чуваню народного здравя и намаганє подзвигнуц на висши уровень общу здравствену културу. У другей статї Солонарова дава совити, описує и толкує цо и як треба вариц слабим и хорим (Солонар 1941б: 137-141). У прилогу такой на початку наводзи же ше у длугорочней апатикарскей пракси вельо занїмала 3 тим питаньом, тримала о тим преподаваня, и сполнює свойо обецанє женом же и у Календаре напише о тим. Вона наводзи "яку важну ролю ма єдзенє у очуваню здравя и же баж зос добрим и прикладним єдзеньом можеме 
найлєгчейше страцене здравє врациц". Далєй у тексту наводзи як треба пририхтовац даєдни єдзеня за слабих и хорих же би ше им и на тот способ врацело страцене зравє.

У остатнїм медзивойновим календаре и др Йосиф Полих ма два прилоги. Перши пошвецени оберацим хоротом (Полих 1941a: 141-17), у котрим автор у уводней часци досц нашироко толкує о бактерийох, о їх дїлованю и успихох медицини у борби процив їх ширеня и у лїченю оберациих хоротох. Тото цо значне за звичайного читача, то описи як ше ширя обераци хороти. То уствари совити и поуки звичайним людзом же би нє доприношели ширеню оберацих хоротох зоз свою негигиєну и нєдзбалством, и же би знали як ше мож чувац од нїх. Лїкар на концу закончує цитируюци другого визначного лїкара: "Чувац ше од хороти лєпше як ше од нєй лїчиц". Други прилог у велькей мири унапрямени на воєни гроженя котри уж вишели над Европу и шветом (Полих 1941б: 147-153). Циль автора информовац и совитовац людзох як ше мож хранїц од нападу з воздуху. Текст ше одноши на организовану охрану и защиту у котрей маю участвовац шицки гражданє и маю добре познац можлїви опасносци котри грожа з воздуху, як ше од нїх скривац и як ше охранїц, и цо шицко треба робиц после воздушного нападу же би одклонїц пошлїдки.

По словох др А. Наливайка медзи Руснацами у Югославиї у чаше медзи двома шветовима войнами була досц розширена очна обераца хорота трахома. У прилогу лїкар нашироко описує цо ю спричинює, як ше шири и яки ма пошлїдки. По його словох, Руснаци як кед би ю уж прилапели як цошка цо нєпреривно провадзи їх живот, и велї ю анї нє лїча, нє знаюци або нє дзбаюци же вона може привесц и до подполного ошлєпеня. На концу наводзи як ше мож чувац од тей хороти: найбаржей зоз чистоту односно особну гигиєну каждей особи и гигиєну у обисцох (Наливайко 1929: 2).

Вироятно же туберкулоза односно єфтика/гефтика, як ю Руснаци волали, була у чаше медзи двома войнами єдна з найчастейших чежших хоротох котра одношела велї животи, часто и млади. Др А. Наливайко у Руских новинох у штирох предлуженьох писал о тей хороти намагаюци ше до дробнїцох упознац Руснацох зоз ню (Наливайко 1931). На початку дава основни податки о тей оберацей хороти описуюци на яки ше способи вона може манифестовац и на котрих органох, а вец обширнєйше преходзи на историят одкриваня бацилох котри ю виволую и описує початки и способи єй лїченя. Ту и поради як ше треба справовац и цо робиц кед дахто у обисцу ма туберкулозу же би ше хорому помогло а здравих зачувало од нєй. Лїкар наглашує же найлєпше односно найефикаснєйше лїченє тей хороти у за тото наменєних санаториюмох, алє то просто нєможлїве за шицких хорих од нєй, а лїченє тиж так можлїве и у домашнїх условийох кед ше у шицким притримує совити лїкарох. По др Наливайкови, Руснаци часто нє досц озбильно приступаю гу тей хороти и нєдосц покладаю на лїченє по якимшик прешвеченю же правда же хори слаби, алє ше озда з часом вилїчи. Як основни ус- 
ловия за лїченє туберкулози и у домашнїх условийох то сила природи: слунко, шветлосц, воздух, добре єдзенє, чистота у хижи и особна гигиєна хорого и шицких у обисцу. Др Наливайко на вецей заводи у Руских каленgapox и Руских новинох писал на рижни теми и о розличних хоротох односно борби процив нїх, алє нє вше з єднаким успихом. Так, наприклад, його статя у двох предлуженьох з насловом Борба за здраве (Наливайко 1935: 146-152) котра пошвецена туберкулози и опасносцом од отровних гасох, поготов у войни, мало приноши нового и того цо наисце може похасновац читачом новинох у лїченю односно чуваню од тих двох вельких опасносцох за людки живот и здравє.

Др А. Наливайко у Руских новинох 1936. року дава обширнєйшу статю у пейц предлуженьох о гуги односно дифтериї у устох и гарлу (Наливайко 1936). Наводзи же ше у остатнїм чаше у Р. Керестуре тота хорота частейше зявює. На початку наводзи же му циль указац як ше тоту хороту лїчи. По його словох, хороту треба почац лїчиц такой кед ше докаже єй присутносц, бо ше з тим барз помага нє лєм хорому, алє ше може онєможлївиц єй ширенє на других. Дохтор дава совити и як ше родичи маю справовац кед дзецко ма гугу и як го маю чувац од векших напруженьох прето же вона барз ослабює шерцо. На концу наводзи же у найновшим чаше у Р. Керестуре були даскельо случаї кед родичи такой на початку хороти приведли дзеци до лїкара и по достатих инекцийох вона застановена. Резултати випитованя гигиєнского заводу у Сомборе доказали же у тих случайох наисце було слово о гуги, а нє о даєдней другей хороти. На концу автор заключує же мож застановиц ширенє оберацих хоротох у валалє и ширше лєм з намаганьом єдного чловека, алє теди кед цала заєднїца будзе мац досц информациї о нїх и кед ше будзе старац же би ше нє ширели.

Дакеди ше у Руских новинох преношело висти о вибераню валалского лїкара. 3 вистох и прилогох о тим у Руских новинох мож заключиц же ше и ту представнїки валалскей власци и политично ангажовани часто нє руководзели з общим интересом валалчаньох, алє мали "власни интереси", були марионети або подлєговали висшей политики або подкупйованю. Так у Руских новинох 1935. року, кед за валалского лїкара бул вибрани др Исидор Леви, Сврей по походзеню, обявена кратка, алє оштра вистка у котрей наведзени аж и мена одборнїкох котри го вибрали, з обвину же им то будзе на ганєбну памятку у валалє (Аноним 1935: 3). Медзитим, тидзень пред тим у Уводнїку Руских новинох було писане о вибору валалского дохтора, дзе автор спомина рижни политични акциї и "тарговини" коло того. Ту вон наглашує же до теди Р. Керестур мал доброго и пожертвованого лїкара, брата Руса (дума на др А. Наливайка - заувага автора), а же єден од кандидатох и др Орос, млади, вредни и способни лїкар. Медзитим, єст таких котри нє дзбаю о народним здравю, алє баржей ту мишаю политику и политиканство (Славянски 1935: 1). На концу ше указало же тоти реакциї обявени у Руских новинох у вязи вибору валалского лїкара нє були без основи. Випатра 
же бул порушани поступок же би ше доказало же вибор др Исидора Левия бул окончени нєзаконїто, бо у юнию 1936. року Управни суд у Београдзе понїщел ришенє срезкого началства у Кули о виборе др И. Левия за лїкара у Р. Керестуре. Ту автор вистки виражел наздаванє Керестурцох же знова за дохтора достаню Русина (Аноним 1936: 4).

Пред другу шветову войну у Р. Керестуре ше зявела идея же би ше у валалє збудовало шпиталь. На жаль, о тим знаме барз мало, и то лєм $3 о з$ одвиту крижевского владики Дионизия Нярадия парохийному уряду у Р. Керестуре. Ту вон наводзи же поздравя "шляхетну намиру вирних будовац шпиталь", и же є порихтани дац глєдану порту за тот циль, алє особнє трима же место нє одвитує за шпиталь прето же $є$ мале и на досц нєвигодним месце. Вон дума же би требало глєдац лєпше место, же би шпиталь бул у цихей часци и же би могол мац и свой парк дзе би ше хори могли одпочивац (АПРК, 233/1938, АКЕ 1008/1938). Нажаль, после того вецей о тим нє находзиме нїяки податки, а очиглядне же идея нє була реализована.

У чаше медзи двома шветовима войнами, кед ше у виданьох Руского народного просвитного дружтва публиковало прилоги з обласци здравства и здравственей защити, авторе и редакторе мали пред собу нєлєгки задаток твориц и хасновац фахову терминологию а источашне вше мац на розуме же тексти писани за звичайни народ, котри найчастейше нє ма анї найосновнєйши знаня з тей обласци. Прето ше вельораз хасновало фахово вирази и назви у комбинациї з народнима, дакеди аж и описово. Було и пробованя присподобиц або твориц нови слова. Лєм глїбша фахова анализа тих виразох и терминологиї би могла дац одвит кельо то було успишне.

Без векших амбицийох приказац общи здравствени обставини при Руснацох у Кральовини СГС/Югославиї, у прилогу зме ше огранїчели у першим шоре на препатрунок прилогох котри були публиковани у виданьох РНПД, у Руских каленgарох и Руских новинох. То углавним прилоги фаховцох, лїкарох и апатикарох, котри нє писани фахово и за фахови цилї и за фахову явносц, алє за звичайних людзох же би ше им дало основни информациї о найчастейших оберацих и других хоротох же би лєгчейше могли препознац їх симптоми и на час ше явиц лїкарови, и же би знали як ше чувац од таких хоротох. Правда, ту єст и надосц практични совити о карменю дзецох, о пририхтованю єдзеньох за хорих и слабих, о приручней апатики, о справованю под час нападу з воздуху итд., а шицко тото мало циль подзвигнуц на висши уровень общу здравствену културу медзи руску популацию у держави. Прето на концу мож заключиц же РНПД праве зоз публикованьом таких прилогох у значней мири допринєсло нє лєм подзвигованю общей здравственей култури, алє же тоти прилоги мали одредзени уплїв и на злєпшованє общого здравственого стану медзи Руснацами у тим периодзе и прето же звекшовали довириє людзох до лїкарох и правого лїченя, а помали викореньовали стари обичаї и праксу лїчиц ше зоз надрилїкарствами и врачанїнами. 


\section{ЖРИДЛА И ЛИТЕРАТУРА:}

Архив Крижевскей епархиї, Крижевци (АКЕ).

Архив парохиї Руски Керестур, Руски Керестур (АПРК).

Аноним (1926). Руски Керестур. Нова апатика. У: Руски новини, 99/1926 (стр. 3). Нови Сад.

Аноним (1935). Виберанка дохтора. Руски новини, 31/1935, стр. 3. Дяково.

Аноним (1936). Руски Керестур. Осуда. Руски новини, 26/1936, стр. 4. Дяково.

А . Н. (Наливайко, А.) (1929а). Обераци хороти. У: Руски календар 1928 (стр. 114-116). Руски Керестур: Руске народне просвитне дружтво.

Биндас, Д. (1926). Суєвериє у нашим народу. У: Руски календар 1925 (стр. 18-27). Руски Керестур: Руске народне просвитне дружтво.

Биндас, Д. - Гайнал, М. (1937). Перши рухи за снованє Руских Новинох. Руски новини, 2/1937, стр. 1-2. Руски Керестур.

Вукич, П. (1996). Павло Вукич и його ”Хистория фари коцурскей”. У: Цап, М. М. (1996).

Церква и школа у Коцуре (стр. 65-114). Нови Сад: Грекокатолїцка парохия св. Петра и Павла Нови Сад.

Жилник, Я. (1924). Чревни тифус (Глушка горячка). Руски новини, 2/1924. стр. 3-4). Нови Сад.

Жильник, Я. (1922). О даскелїх оберацих (порядкових) хоротох. У: Руски календар 1922 (стр. 115-122). Руски Керестур: Руске народне просвитне дружтво.

Жирош, М. (1997). Бачванско-сримски Руснаци дома и у швеце, т. І. Нови Сад: Грекокатолїцка парохия св. Петра и Павла у Новим Садзе.

Жирош, М. (1984) Три керестурски колери (1-2). Шветлосц, 3/1984, 351-367, 4/1984, 458-480. Нови Сад: Руске слово.

Жирош, М. (1986). Три коцурски колери. Шветлосц, 1/1986 , 71-97. Нови Сад: Руске слово.

Јеремић, Р. (1928). Бачки Руси (Рушњаци, Русини). У: Прилози Летопису Матице српске, књ. I, св. 2, год. I, март-април 1928 (стр. 49-67). Нови Сад: Матица српска.

Костельник. Г. (1998). Liber memorabilium грекокатолїцкей парохиї бачкерестурскей. Нови Сад: Союз Руснацох и Українцох Югославиї.

Кочиш, Е. (1930). О даєдних звичайох. Руски новини, 20/1930, 1. Нови Сад.

Лабош, О. А. (1931). Перша помоц при нєщесцох отровеня. У: Руски календар 1931 (стр.140-147). Руски Керестур: Руске народне просвитне дружтво.

Микић, П. (1989). Записи о рађању и умирању деце у Новом Саду и Војводини током XIX и XX века. Нови Сад: Матица српска.

Москаль, Й. (1923). Народна кроника. У: Руски календар 1923 (стр. 78-83). Р. Керестур: Руске народне просвите дружтво.

Наливайко, А. (1928). Обераци хороти. У: Руски календар 1928 (стр. 114-116). Р. Керестур: Руске народне просвитне дружтво.

Наливайко, А. (1935). Борба за здраве. Руски новини, 24/1935, 3; 25/1935, 2. Дяково.

Наливайко, А. (1929). Трахома. Руски новини, 6/1929, 2. Нови Сад.

Наливайко, А. (1935). О допатраню дзецох у першим року живота. У: Руски календар 1935 (стр, 146-152). Руски Керестур: Руске народне просвитне дружтво.

Наливайко, А. (1931). Туберкулоза - гефтика. Руски новини, 9/1931, 3; 10/1931, 4; 11/1931, 3; 12/1931, 4. Дяково. 
Наливайко, А. (1936). Гуга (дифтерия) у устох и гарлу. Руски новини, 36/1936, 4; 37/1936, 3-4; 38/1936, 4; 39/1936, 3-4; 40/1936, 3-4. Дяково.

Наливайко, А. (1936). Чуванє здравя. У: Руски календар 1936 (стр. 124-127). Р. Керестур: Руске народне просвитне дружтво.

Палич-Санто, О. (1932). Причини шлєпоти. У: Руски календар 1932 (стр. 117-119). Руски Керестур: Руске народне просвитне дружтво.

Полих, О. (1925).О здравству. А.) Причини умераня дзецох. У: Руски календар 1925 (стр. 97-99). Руски Керестур: Руске народне просвитне дружтво.

Полих, О. (1940). Як очувац дзеци од оберацих хоротох. У: Руски календар 1940 (стр. 154-160). Руски Керестур: Руске народне просвитне дружтво.

Полих, Й. (1941a). Найвекши нєприятелє чловека бактериї и обераци хороти. У: Руски календар 1941 (стр. 141-147). Руски Керестур: Руске народне просвитне дружтво.

Полих, Й. (1941б). Роздумованя о охрани од нападу з воздуху. У: Руски календар 1941 (стр. 147-153). Руски Керестур: Руске народне просвитне дружтво. Правила (1921). Правила "Руского народного просвьтного друштва". У: Руски календар 1921 (стр. 8-12). Р. Керестур: Руске народне просвитне дружтво.

Рамач, Я. (2007). Руснаци у Южней Угорскей (1745-1918). Нови Сад: Войводянска академия наукох и уметносцох.

Рамач, Я. (1988). Спомин вични керестурски або Спомин од створеня швета. Шветлосц, 5/1988, 527-550. Нови Сад: Руске слово.

Славянски (Буїла, М.). Важна ствар (Наш дохторски вопрос). Руски новини, 30/1935, 1. Дяково.

Солонар, С. (1940). Як кармиц мали дзеци. У: Руски календар 1940 (стр. 160-164). Руски Керестур: Руске народне просвитне дружтво.

Солонар-Поливка, С. (1941a). Ручна апатика. У: Руски календар 1941 (стр. 133-137). Руски Керестур: Руске народне просвитне дружтво.

Солонар-Поливка, С. (1941б). Як треба вариц хорим и слабим. У: Руски календар 1941 (стр. 137-141). Руски Керестур: Руске народне просвитне дружтво.

Черняк, М. (1922). О алкоголю. У: Руски календар 1922 (стр. 85-91). Руски Керестур: Руске народне просвитне дружтво. 
Ramač Janko

\section{SUPPLEMENTS ON HEALTH CARE AND ITS PROTECTION IN THE PUBLICATIONS OF THE RUTHENIAN NATIONAL EDUCATIONAL SOCIETY} (1921-1941)

\section{SUMMARY}

In the period between the two world wars, The Ruthenian National Educational Society (Association), besides its basic activity in the field of the cultural, educational and national life of the Ruthenians in Yugoslavia, paid a significant attention to raising their general social and economic progress. This article shows the striving to contribute to raising the general health care and its protection among the broadest layers of the Ruthenian population by supplements and articles in the publications of the Ruthenian National Educational Society, such as the Ruthenian Calendars (1921-1941) and the Ruthenian Newspaper (1924-1941). The authors of these articles were general practitioners, specialists and pharmacists who had been well acquainted with the health issues in Ruthenian settlements. Taking into account the fact that the Ruthenian Calendars were published in 2 500-3 000 coppies, and the Ruthenian Newspaper in about a thousand coppies, we can conclude that these articles reached a great part of the Ruthenian families and played a significant role in raising the level of the general health care and health protection especially against contagious diseases.

Key words: Ruthenian National Educational Society, Ruthenians in Yugoslavia, Ruthenian Calendars, Ruthenian Newspaper, health culture, protection of health, contagious diseases. 